\title{
First-line antibiotic susceptibility pattern of toxigenic Corynebacterium diphtheriae in Indonesia
}

Dominicus Husada ${ }^{1 *}$ D, Sugi Deny Pranoto Soegianto ${ }^{1}$, Indra Suwarin Kurniawati ${ }^{2}$, Adi Pramono Hendrata ${ }^{2}$, Eveline Irawan ${ }^{2}$, Leny Kartina ${ }^{1}$, Dwiyanti Puspitasari ${ }^{1}$, Parwati Setiono Basuki ${ }^{1}$ and Ismoedijanto $^{1}$

\begin{abstract}
Background: Diphtheria has been reported as an outbreak in some regions in Indonesia, most especially in East Java Province. Resistance to penicillin, erythromycin, and other antibiotics, single or multiple, has been reported in several studies. This study aims to evaluate the first-line antibiotic susceptibility pattern of toxigenic Corynebacterium diphtheriae isolates.

Methods: This descriptive observational study was performed from August to November 2018. C. diphtheriae isolates were collected from diphtheria patients and carriers in East Java from 2012 to 2017 and kept at the Balai Besar Laboratorium Kesehatan Daerah Surabaya or the Public Health Laboratory of Surabaya. Sample selection was done by random cluster sampling. The sensitivity test by E-test ${ }^{\oplus}$ of the five antibiotics (penicillin, oxacillin, erythromycin, azithromycin, and clarithromycin) was done to determine the minimum inhibitory concentration (MIC). The Clinical and Laboratory Standards Institute M45A (2015) Corynebacterium spp. for penicillin and erythromycin was used as standard.
\end{abstract}

Results: From 114 targeted isolates, 108 were viable and toxigenic. The E-test was performed on the viable isolates. The majority of the hosts were male (58.3\%), with median (range) age of 6.5 (1-14) years. Half of the samples were from the 1 to 5-year-old age group. The isolates were acquired much more from patients (78.7\%) than carriers (21.3\%) and from pharyngeal swab (74.1\%). Most of these isolates were from Madura Island (47.2\%) and the northern and eastern parts of the province (horseshoe area). Mitis isolates were the major variant (76.9\%). The susceptibility pattern of $C$. diphtheriae to erythromycin was better than that to penicillin. The E-test result for penicillin was $68.52 \%$ susceptible, 31.48\% intermediate, and 0\% resistant (MIC range, $<0.016$ to $2 \mu \mathrm{g} / \mathrm{L}$ ) and for erythromycin (MIC range, $<0.016$ to $>256 \mu \mathrm{g} / \mathrm{L}$ ) was $85.2 \%$ susceptible, $12 \%$ intermediate, and $2.8 \%$ resistant The MIC range for oxacillin was 1 to $96 \mu \mathrm{g} / \mathrm{L}$, while for both azithromycin and clarithromycin were $<0.016$ to $>256 \mu \mathrm{g} / \mathrm{L}$.

Conclusion: The susceptibility rate of $C$. diphtheriae to erythromycin is higher than that to penicillin. The regular update of antibiotic selection to the national guidelines is recommended. The MIC reference standard to azithromycin and clarithromycin is also needed.

Keywords: First line antibiotics, Penicillin, Erythromycin, Susceptibility pattern, Corynebacterium diphtheriae, Toxigenic, Indonesia

\footnotetext{
* Correspondence: dominicushusada@yahoo.com

${ }^{1}$ Department of Child Health, Faculty of Medicine Universitas Airlangga/Dr.

Soetomo Academic General Hospital, Surabaya, Indonesia

Full list of author information is available at the end of the article
}

(c) The Author(s). 2019 Open Access This article is distributed under the terms of the Creative Commons Attribution 4.0 International License (http://creativecommons.org/licenses/by/4.0/), which permits unrestricted use, distribution, and reproduction in any medium, provided you give appropriate credit to the original author(s) and the source, provide a link to the Creative Commons license, and indicate if changes were made. The Creative Commons Public Domain Dedication waiver (http://creativecommons.org/publicdomain/zero/1.0/) applies to the data made available in this article, unless otherwise stated. 


\section{Background}

There has been a high number of diphtheria cases in Indonesia since 2011. East Java Province is the most endemic area of these cases, and the only province officialy declared with diphtheria outbreak. Almost $80 \%$ of the cases in Indonesia are in this province [1, 2]. Despite many efforts to tackle the outbreak, these diphtheria problems have not been stopped [2]. All aspects of prevention and treatment, including the antibiotic resistance factor, have been evaluated in this province. Basically, there are two main treatments of diphtheria, anti diphtheria serum (ADS) and antibiotics. ADS binds the free toxin in the circulation. The toxin that is already inside the cell cannot be neutralized by this ADS. Antibiotic therapy plays other significant roles in diphtheria management [3-6]. The availability of ADS in Indonesia becomes very limited due to supply shortage [7, 8]; for several years, many patients in Indonesia could not received ADS. Just recently, the only national vaccine manufacturer in Indonesia has produced ADS to fulfill this gap. This condition might add a more significant role for antibiotics as an important treatment for diphtheria.

Antibiotics are needed to kill the toxigenic Corynebacterium diphtheriae, stop the toxin production and the dissemination in symptomatic patients and clinical disease, and reduce the spread from asymptomatic carriers and the colonization of close contacts [3-6]. Penicillin and macrolide are groups of empirical antibiotics used to eradicate toxigenic $C$. diphtheriae based on the World Health Organization (WHO) and the Centers for Disease Control and Prevention (CDC) guidelines for the treatment of diphtheria $[9,10]$. Penicillin is the standard treatment for diphtheria since the 1940s [11]. Some studies have already reported on the increase of resistant isolates of this toxigenic bacteria [12-15].

The emergence of antibiotic resistance to $C$. diphtheriae has made a serious concern in some countries [3, 16-20]. It is also possible that the decreased susceptibility to penicillin is a cause of $C$. diphtheriae eradication failure $[3,21]$. During this period of high number of diphtheria cases in East Java, there are no data regarding the first-line antibiotic susceptibility pattern of $C$. diphtheriae. The first-line antibiotics include penicillin and macrolides.

Erythromycin has been recommended as the drug of choice for diphtheria for such a long time, but several studies have reported the decrease of susceptibility to this drug [12-15]. The other problem with this drug is its gastrointestinal effect [4]. In our clinical settings, only a few people can finish the 7-day procedure of erythromycin. The cardiac side effect of erythromycin has been reported in the 1980s [22]. However, no such data in diphtheria patients and carriers have been collected and reported in Indonesia. Erythromycin is available in the country in oral forms only.
The WHO has also added azithromycin as part of the standard antibiotics for diphtheria [23]. Azithromycin is successfully used for other infectious diseases such as typhoid fever [24]. Azithromycin has not been used widely for diphtheria patients in Indonesia but it is wellknown by many clinicians and is available all over the country. Clarithromycin, also mentioned by a few guidelines [25], is used only by a few clinicians at present. This drug has several advantages. It has milder gastrointestinal effects compared to erythromycin [26], and in Indonesia has lower costs than that of azithromycin.

Aside from all the first-line antibiotics mentioned above, oxacillin, one of the drugs from the penicillinaseresistant-semisynthetic-penicillin group, has been added in this study. This drug has some advantages which include good bioavailability and administration choice by intramuscular or intravenous injection [27]. Its potency, especially for Gram-positive bacteria, and availability in most areas in Indonesia (sometimes better than the availability of penicillin) are also taken into account.

This study aims to evaluate East Java toxigenic $C$. diphtheriae isolates for their susceptibility to penicillin, oxacillin, and macrolide group of antibiotics. The result of this study, hopefully, can be used as a basis to maintain or change the antibiotic choices as one of the main treatments of diphtheria in Indonesia.

\section{Methods}

\section{Laboratory}

Balai Besar Laboratorium Kesehatan Daerah (BBLK) Surabaya or the Public Health Laboratory of Surabaya is one of the two referral laboratories for diphtheria in Indonesia. This laboratory is located in Surabaya, the second-largest city in Indonesia, covering the whole area of the eastern part of the country. The BBLK has international accreditation and is a referral laboratory for diphtheria, polio, and measles cases in Indonesia. All $C$. diphtheriae isolates from East Java and the eastern part of Indonesia were collected at this laboratory.

\section{Collection of toxigenic $C$. diphtheriae isolates}

C. diphtheriae isolates were collected from diphtheria patients and carriers during outbreaks in East Java, especially from 2012 to 2017. After that, specimens from each swab (nose and throat) were placed in Amies transport media (Deltalab SL, Barcelona, Spain) and transported within $24 \mathrm{~h}$ at $2{ }^{\circ} \mathrm{C}$ to $8{ }^{\circ} \mathrm{C}$ from the original districts to the BBLK, where the specimens were cultured in Hoyle media (Oxoid, Basingstoke, Hampshire, United Kingdom) for 24 to $48 \mathrm{~h}$. Then, Grampositive colonies were recultured on Columbia agar (Oxoid). Several following tests using pyrazinamidase, cysteinase, urea, and nitrate [28] and biochemical tests (API CorynE-test Kit; Biomerieux, Marcy l'Etoile, 
France) were performed. The final procedure was a modified Elek test to confirm the toxigenicity [29]. The whole process took 5 to 7 days. After all thE-tests, these isolates, were later stored in trypticase soy broth with $20 \%$ glycerol at $-80{ }^{\circ} \mathrm{C}$.

\section{Sample size and sample selection}

The minimal sample size was calculated by the Krejcie and Morgan formula for a limited population with $\alpha=$ $0.05, Z=1.96$, and deviation $(d)=0.05$. The total isolate collection from 2011 to 2017 at the BBLK was 200. Based on the formula, the minimal sample requirement was 104.

Among all isolates at the BBLK, the samples were chosen by random cluster sampling system. The cluster was based on the district's distribution. In every cluster, the isolates were proportionally selected based on the proportion of samples at that particular district to the total isolates. Madura Island, and the northern and eastern parts of the province were prioritized because most of the patients and carriers during the diphtheria outbreak in East Java were from these areas [2]. These heavily affected districts were called collectively as the horseshoe area based on its shape in the map [30]. People in the horse-shoe area were predominantly from Madura ethnicity. This ethnic group has specific characteristics. Madura people generally have lower economic and educational status [30].

\section{Viability and toxigenicity tests}

The viability and toxigenicity tests were performed from August to November 2018. The isolates were recultured on Hoyle media and Columbia agar and then re-identified with somE-tests, similar to the standard procedure during the initial collection process. Also the modified Elek test was performed to check the toxigenicity. If the isolates were viable and toxigenic, then the E-test procedure was done.

\section{E-test strips}

The E-test strips of benzylpenicillin PG256 (code BMX502508), erythromycin EM256 (code BMX510518), azithromycin AZ256 (code BMX501618), clarithromycin CH256 (code BMX508708), and oxacillin OX256 (code BMX520518) were used. All E-tests were from Biomerieux ${ }^{\oplus}$.

\section{E-test procedure and interpretation of the results}

The E-test ${ }^{\oplus}$ was performed on the viable and toxigenic isolates based on the instructions by the manufacturer. Basically, the isolates were placed on Columbia blood agar plate (BAP) and incubated for $24 \mathrm{~h}$. On the viable isolates, the E-test strips were placed on the inoculation site of BAP using manual applicator forceps. The temperature was set at $35^{\circ} \mathrm{C}$ on ambient atmosphere for 16 to $20 \mathrm{~h}$.
This method was used to determine the minimum inhibitory concentration (MIC; in $\mu \mathrm{g} / \mathrm{L}$ ) of different antimicrobial agents against microorganisms as tested on agar media using overnight incubation. The MIC interpretative standard in this study was based on the Clinical and Laboratory Standards Institute (CLSI) M45A (2015) Corynebacterium spp. for penicillin and erythromycin [31]. The MIC standard for penicillin was $\leq 0.12,0.25$ to 2 , and $\geq 4 \mu \mathrm{g} / \mathrm{ml}$ for susceptible $(\mathrm{S})$, intermediate (I), and resistant $(\mathrm{R})$, respectively, while the MIC standard for erythromycin is $\leq 0.5,1$, and $\geq 2 \mu \mathrm{g} / \mathrm{ml}$, for $\mathrm{S}$, I, and $\mathrm{R}$, respectively [31]. There were no MIC criteria for oxacillin, azithromycin and clarithromycin for Corynebacterium on CLSI, therefore the MIC data were presented without any interpretation of susceptibility.

In this study, both "intermediate" and "resistant" categories were grouped as "less susceptible". Multiresistant antibiotics were defined as resistant to more than one drug.

\section{Statistical analysis}

Statistical analysis was performed with a descriptivE-test by $\mathrm{IBM}^{\oplus} \mathrm{SPSS}^{\oplus}$ version 20 for Mac OS.

\section{Results}

Initially, 114 isolates were selected. Among them, 6 isolates were nonviable; therefore, 108 viable isolates could bE-tested for the E-test at the end. The characteristics of the 108 toxigenic $C$. diphtheriae isolates and the hosts are shown in Table 1. Most of the hosts were patients $(78.7 \%)$, and boys $(58.3 \%)$, and belong to the $\leq$ 5 -year-old age group (50\%). The predominant districts were Madura Island and the northern and eastern parts of the province as mentioned earlier. Most biotypes of C. diphtheriae in this study were mitis (76.9\%). Eighty isolates ( 80 of $108 ; 74.1 \%$ ) came from the pharynx. The years with the most cases were 2013 (35.2\%) and 2017 (32.4\%).

The MIC range of penicillin $(<0.016$ to $2 \mu \mathrm{g} / \mathrm{L})$ and erythromycin $(<0.016$ to $>256 \mu \mathrm{g} / \mathrm{L})$ and the resistance number of isolates are shown in Table 2. The susceptible rate for erythromycin (85.19\%) was higher than that of penicillin (68.52\%). There were no resistant isolates to penicillin, compared to the three resistant isolates to erythromycin. For both antibiotics, most of the less susceptible isolates were gravis biotype [24 of 36 (66.67\%) for penicillin, and 16 of 16 (100\%) for erythromycin]. All less susceptible isolates to erythromycin were also less susceptible to penicillin.

The MIC data of oxacillin, azithromycin, and clarithromycin are shown in Table 3. The MIC range for oxacillin, azithromycin, and clarithromycin were 1 to 96 , $<0.016$ to $>256$, and $<0.016$ to $>256 \mu \mathrm{g} / \mathrm{L}$, respectively. Figure $1 \mathrm{a}-\mathrm{e}$ shows the bar diagram of the MIC of the 
Table 1 Characteristics of toxigenic C. diphtheriae isolates and the hosts

\begin{tabular}{|c|c|c|}
\hline \multicolumn{3}{|l|}{ Host characteristics } \\
\hline Sex & (n) & (\%) \\
\hline Male & 63 & 58.3 \\
\hline Female & 45 & 41.7 \\
\hline Age, median (min-max) & \multicolumn{2}{|c|}{$6.5(1-14)$ years } \\
\hline Group age & $(n)$ & (\%) \\
\hline $1-5$ years & 54 & 50 \\
\hline$>5-10$ years & 33 & 30.6 \\
\hline$>10-15$ years & 21 & 19.4 \\
\hline Host status & (n) & (\%) \\
\hline Patients & 85 & 78.7 \\
\hline Carriers & 23 & 21.3 \\
\hline \multicolumn{3}{|l|}{ Isolate characteristic } \\
\hline Year of isolate collection & (n) & (\%) \\
\hline 2012 & 7 & 6.5 \\
\hline 2013 & 38 & 35.2 \\
\hline 2014 & 7 & 6.5 \\
\hline 2015 & 15 & 13.9 \\
\hline 2016 & 6 & 5.6 \\
\hline 2017 & 35 & 32.4 \\
\hline Area of isolate collection & (n) & (\%) \\
\hline Madura Island & 51 & 47.2 \\
\hline Northern and eastern parts of East & 35 & 32.4 \\
\hline \multicolumn{3}{|l|}{ Java (Horseshoe area) } \\
\hline Other parts of East Java & 22 & 20.4 \\
\hline Sites of isolate collection & (n) & (\%) \\
\hline Pharyngeal swab & 80 & 74.1 \\
\hline Nose swab & 28 & 25.9 \\
\hline C. diphtheriae variant & $(n)$ & (\%) \\
\hline Gravis & 25 & 23.1 \\
\hline Mitis & 83 & 76.9 \\
\hline Intermedius & 0 & 0 \\
\hline Belfanti & 0 & 0 \\
\hline
\end{tabular}

five antibiotics. Higher MIC was found for oxacillin. For all antibiotics, most gravis biotypes were in higher MIC than mitis. Figure 2 compares the MIC of three macrolides, focusing on isolates with reduced susceptibility to erythromycin. Most of the less susceptible isolates to erythromycin also had high MIC to azithromycin, but possibly not to clarithromycin.

\section{Discussion}

In 2017, the WHO has released the latest operational protocol for the clinical management of diphtheria. The recommended antibiotics were penicillin, such as
Table 2 MIC, variants and CLSI interpretation of toxigenic C. diphtheriae isolates for penicillin and erythromycin

\begin{tabular}{lllll}
\hline $\begin{array}{l}\text { Antibiotics } \\
\text { and biotype }\end{array}$ & $\begin{array}{l}\text { MIC range } \\
(\mu \mathrm{g} / \mathrm{L})\end{array}$ & \multicolumn{4}{l}{ Interpretation according to CLSI M45A } \\
\cline { 3 - 5 } & $\mathrm{S}$ & $\mathrm{S}$ & $\mathrm{I}$ & $\mathrm{R}$ \\
\hline Penicillin & $<0.016$ to 2 & $74(68.52 \%)$ & $36(31.48 \%)$ & $0(0 \%)$ \\
Gravis & & 1 & 24 & 0 \\
Mitis & & 73 & 12 & 0 \\
Erythromycin & $<0.016$ to & $92(85.19 \%)$ & $13(12.04 \%)$ & $3(2.77 \%)$ \\
Gravis & $>256$ & 9 & 13 & 3 \\
Mitis & & 83 & 0 & 0
\end{tabular}

Source: CLSI M45A (2015) penicillin for Corynebacterium spp. (S) $\leq 0.12 \mu \mathrm{g} / \mathrm{L}$, (I) 0.25 to $2 \mu \mathrm{g} / \mathrm{L}$, and $(\mathrm{R}) \geq 4 \mu \mathrm{g} / \mathrm{L}$; for erythromycin: (S) $\leq 0,5 \mu \mathrm{g} / \mathrm{L}$, (I) $1 \mu \mathrm{g} / \mathrm{L}$ (R), and $\geq 2 \mu \mathrm{g} / \mathrm{L} ; \mathrm{S}=$ Susceptible; $\mathrm{R}=$ Resistant; I=Intermediate

procaine benzylpenicillin and aqueous benzylpenicillin (penicillin G), and macrolides, such as erythromycin and azithromycin [23]. Other recommendations such as from the South African National Institute for Communicable Diseases and United Kingdom (UK) guidelines for the control of diphtheria have stated that clarithromycin as a drug of choice could be used to clear the $C$. diphtheriae infection [25]. In addition, clarithromycin as the main antibiotic for diphtheria have been already used by some clinicians [32, 33]. These antibiotics are active against $C$. diphtheriae [34]. In Indonesian Guidelines, the two main antibiotics are procaine penicillin and erythromycin [35]. There is no registered intravenous penicillin or intravenous erythromycin in Indonesia. Based on the WHO recommendations, some clinicians use azithromycin as another choice of antibiotic [23]. As far as we concerned, there is no publication regarding resistance data and the clinical use of azithromycin and clarithromycin for diphtheria patients and carriers in Indonesia.

During the outbreak, the boys slightly outnumbered the girls, which also happened in the distribution of the host of these isolates. In several diphtheria outbreaks in the world, such as in the former Soviet Union, in which most of the patients were adults, females were predominant [36]. The assumption was that males received more vaccination for diphtheria and tetanus because of military duties and being more likely to have infected wounds [37]. In many developing countries, such as India and Vietnam, the majority of the patients and carriers were children $[5,14,38]$, while most of the patients during the former Soviet Union outbreak were adults [36]. The high incidence in children ages $<5$ years old showed low vaccination coverage. In contrast, the good primary vaccination coverage among babies would create a shift, and most of the patients were preschool and school-aged children [3, 16]. However, historical data showed that the shift to older ages has already been started before the mass immunization era due to several 
Table 3 MIC of C. diphtheriae to Oxacillin, Azithromycin, and Clarithromycin

\begin{tabular}{|c|c|c|c|c|c|c|c|c|c|}
\hline \multirow{2}{*}{$\begin{array}{l}\text { MIC } \\
(\mu \mathrm{g} / \mathrm{L})\end{array}$} & \multicolumn{3}{|c|}{ OXACILLIN (range, 1 to $96 \mu \mathrm{g} / \mathrm{L}$ ) } & \multicolumn{3}{|c|}{ AZITHROMYCIN (range, $<0.016$ to $>256 \mu \mathrm{g} / \mathrm{L}$ ) } & \multicolumn{3}{|c|}{ CLARITHROMYCIN (range, $<0.016$ to $>256 \mu \mathrm{g} / \mathrm{L}$ ) } \\
\hline & Total & Mitis & Gravis & Total & Mitis & Gravis & Total & Mitis & Gravis \\
\hline$<0.016$ & 0 & 0 & 0 & 13 & 12 & 1 & 79 & 77 & 2 \\
\hline 0.016 & 0 & 0 & 0 & 21 & 21 & 0 & 7 & 3 & 4 \\
\hline 0.023 & 0 & 0 & 0 & 30 & 30 & 1 & 2 & 2 & 0 \\
\hline 0.032 & 0 & 0 & 0 & 14 & 14 & 0 & 1 & 0 & 1 \\
\hline 0.047 & 0 & 0 & 0 & 0 & 0 & 0 & 1 & 1 & 0 \\
\hline 0.064 & 0 & 0 & 0 & 1 & 1 & 0 & 0 & 0 & 0 \\
\hline 0.094 & 0 & 0 & 0 & 1 & 1 & 0 & 0 & 0 & 0 \\
\hline 0.125 & 0 & 0 & 0 & 1 & 1 & 0 & 1 & 0 & 1 \\
\hline 0.19 & 0 & 0 & 0 & 1 & 0 & 1 & 1 & 0 & 1 \\
\hline 0.25 & 0 & 0 & 0 & 0 & 0 & 0 & 0 & 0 & 0 \\
\hline 0.38 & 0 & 0 & 0 & 2 & 2 & 0 & 2 & 0 & 2 \\
\hline 0.50 & 0 & 0 & 0 & 0 & 0 & 0 & 2 & 0 & 2 \\
\hline 0.75 & 0 & 0 & 0 & 1 & 0 & 1 & 1 & 0 & 1 \\
\hline 1 & 4 & 4 & 0 & 0 & 0 & 0 & 3 & 0 & 3 \\
\hline 1.5 & 30 & 30 & 0 & 1 & 1 & 0 & 3 & 0 & 3 \\
\hline 2 & 24 & 23 & 1 & 2 & 1 & 1 & 2 & 0 & 2 \\
\hline 3 & 20 & 19 & 1 & 0 & 0 & 0 & 0 & 0 & 0 \\
\hline 4 & 11 & 4 & 7 & 0 & 0 & 0 & 0 & 0 & 0 \\
\hline 6 & 6 & 1 & 5 & 2 & 0 & 2 & 0 & 0 & 0 \\
\hline 8 & 9 & 1 & 8 & 0 & 0 & 0 & 1 & 0 & 1 \\
\hline 12 & 2 & 1 & 1 & 0 & 0 & 0 & 0 & 0 & 0 \\
\hline 16 & 0 & 0 & 0 & 1 & 0 & 1 & 1 & 0 & 1 \\
\hline 24 & 1 & 0 & 1 & 3 & 0 & 3 & 0 & 0 & 0 \\
\hline 32 & 0 & 0 & 0 & 4 & 0 & 4 & 0 & 0 & 0 \\
\hline 48 & 0 & 0 & 0 & 4 & 0 & 4 & 0 & 0 & 0 \\
\hline 64 & 0 & 0 & 0 & 0 & 0 & 0 & 0 & 0 & 0 \\
\hline 96 & 1 & 0 & 1 & 1 & 0 & 1 & 0 & 0 & 0 \\
\hline 128 & 0 & 0 & 0 & 0 & 0 & 0 & 0 & 0 & 0 \\
\hline 192 & 0 & 0 & 0 & 0 & 0 & 0 & 0 & 0 & 0 \\
\hline 256 & 0 & 0 & 0 & 1 & 0 & 1 & 0 & 0 & 0 \\
\hline$>256$ & 0 & 0 & 0 & 4 & 0 & 4 & 1 & 0 & 1 \\
\hline
\end{tabular}

factors such as crowding and poor personal hygiene [16].

Mitis biotypes were predominant in this study, similar to several results from France, [39], Algeria, [40], Malaysia, [41], Brazil, [3], United Kingdom, [15], and previous studies in Indonesia [42, 43]. In Poland and another study in United Kingdom, the majority of the biotypes were gravis $[4,44]$. Gravis biotypes in Vietnam and Algeria caused more severe clinical forms [5, 40]. .

Our result in Table 2 showed higher susceptibility of C. diphtheriae to erythromycin compared to penicillin. Most less susceptible isolates to penicillin were gravis biotype. Rockhill et al. in 1982 using disk diffusion method (10 IU penicillin and $15 \mu \mathrm{g}$ erythromycin) showed that all (133 of 133) C. diphtheriae isolates from Jakarta were susceptible to penicillin [42]. Kneen et al. in 1998 also using disk diffusion method (10 IU penicillin and $15 \mu \mathrm{g}$ erythromycin) showed that all (15 of 15) isolates of their study in Vietnam were susceptible to penicillin. Gravis biotypes caused more severe clinical forms [5]. The result of the susceptibility test by Engler et al. in 2001 in the United Kingdom (with 410 C. diphtheriae isolates from 1988 to 1998) showed that penicillin $G$ was active against all isolates $\left(\mathrm{MIC}_{90}, 0.43 \mathrm{mg} / \mathrm{L}\right)$. Agar dilution method and confirmation with E-test were used in this study [4]. In Brazil, Pereira et al. reported that 


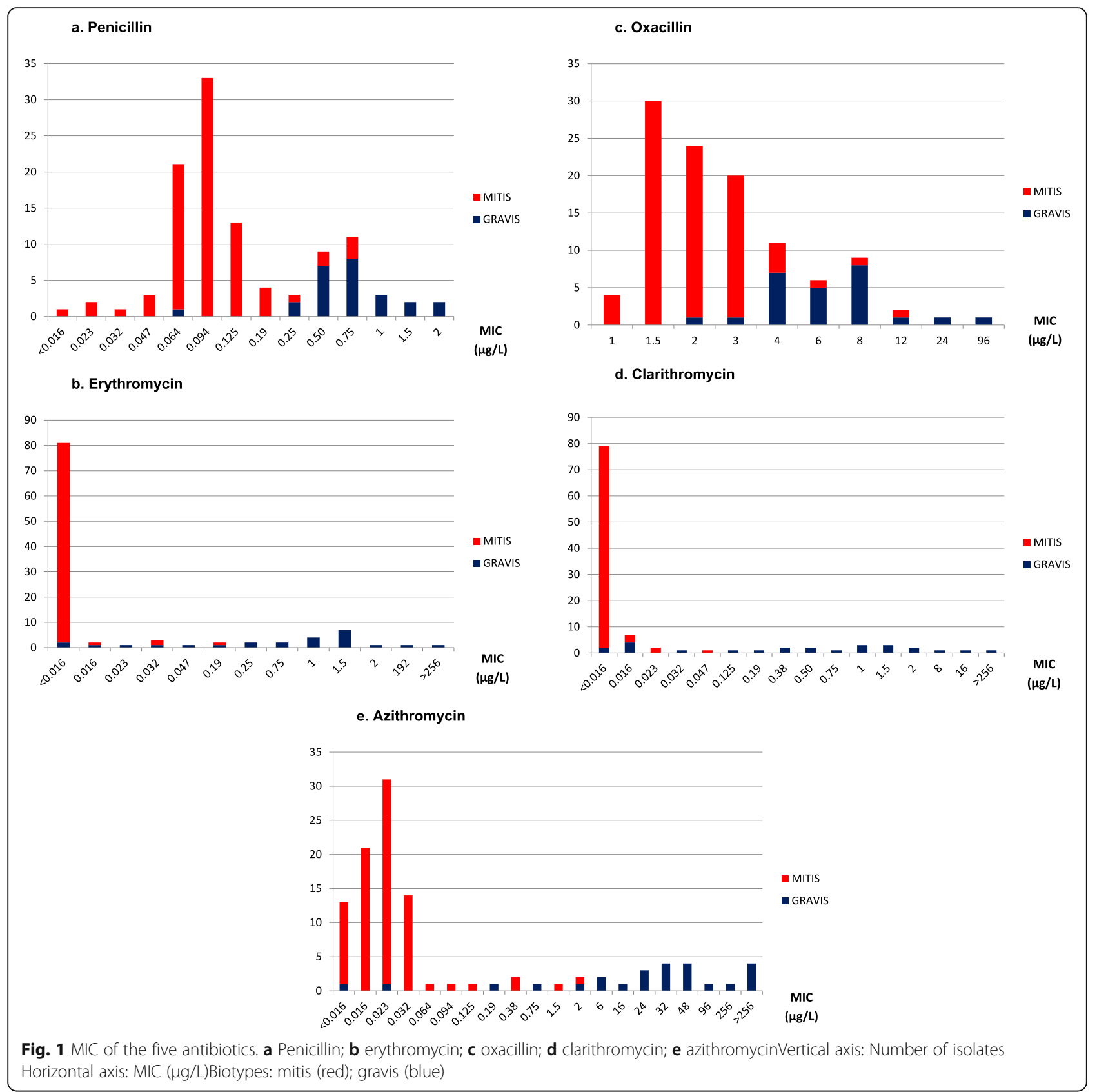

resistance to penicillin $\mathrm{G}\left(\mathrm{MIC}_{90}, 0.19 \mu \mathrm{g} / \mathrm{L}\right)$ was found in $14.8 \%$ (7 of 47) of thE-tested isolates. They also used disk diffusion method and E-test for the study. Since at that time CLSI did not provide the MIC breakpoints obtained by disk diffusion method for coryneform bacteria, the authors used the breakpoints for Staphylococcus aureus [3]. In France, a study by Patey et al. found that all isolates (38 of 38) were susceptible to penicillin. This study used disk diffusion method (6 $\mu$ g penicillin) [39]. In New Delhi India, Sharma et al. reported that all isolates (54 of 54) were susceptible to penicillin. Also, this study used disk diffusion method (10 IU penicillin and
$15 \mu \mathrm{g}$ erythromycin) [45]. More recently, in Canada, Bernard et al. showed 100\% susceptibility of 195 C. diphtheriae isolates from all over the country to penicillin. This study used broth microdilution and CLSI 2015 as standard [20]. In contrast to all studies above, an epidemiology study of diphtheria and antimicrobial resistance among diphtheria cases in Bijapur District, Karnataka, India, from 2012 to 2015 by Mohankumar et al. showed very high incidence of penicillin resistance, of about $92 \%$ (24 of 26) of cases [46]. Unfortunately we could not get any additional data of this study from the literature. Another study from Thailand by Paveenkittiporn 


\section{a. Resistant isolates to erythromycin}

$\operatorname{MIC}(\mu \mathrm{g} / \mathrm{L})$

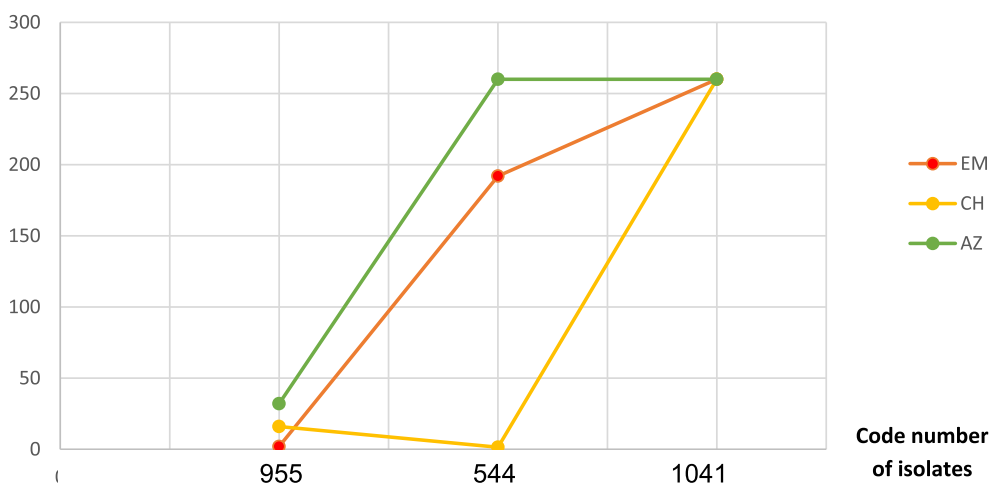

b. Intermediate isolates to erythromycin

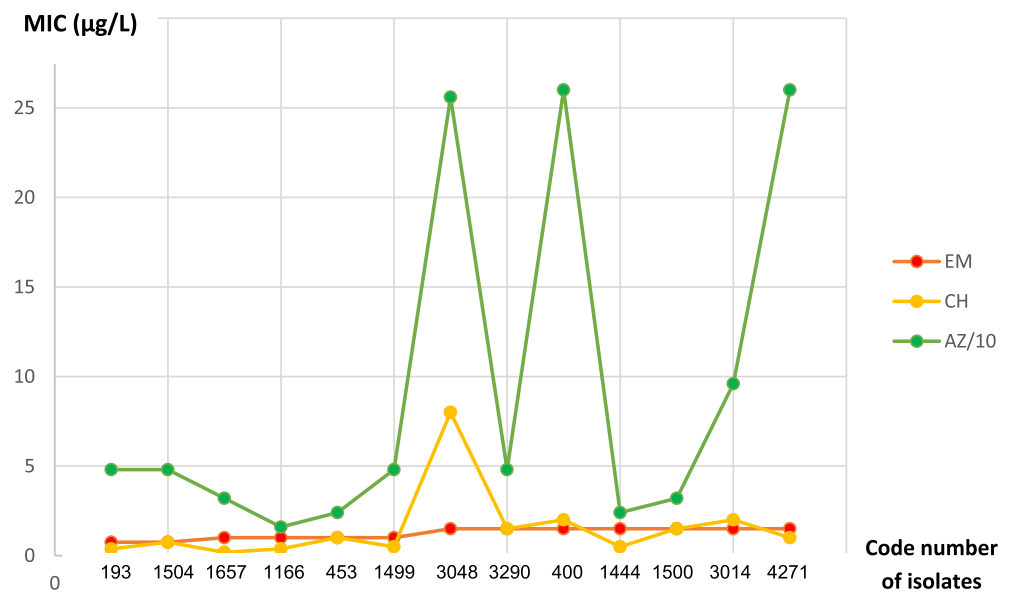

Fig. 2 Comparison of MIC of the three macrolides, focusing on less susceptible isolates to erythromycin a Resistant isolates to erythromycin (3 isolates). $\mathbf{b}$ Intermediate isolates to erythromycin (13 isolates)Vertical axis: MIC ( $\mu \mathrm{g} / \mathrm{L})$; In Fig. 2b, the MIC of azithromycin was one tenth of the real valueHorizontal axis: code number of isolatesColor: erythromycin/EM (red), clarithromycin/CH (yellow), azithromycin/AZ (green)

et al. also showed reduced susceptibility to penicillin. All isolates (41 of 41) were in the intermediate category against penicillin. Broth microdilution and CLSI 2015 were used as standard [19]. An evaluation of isolates from 1992 to 2005 in Algeria found reduced susceptibility in 90 of 157 (57.3\%) samples. This study used E-test with CLSI 2015 as standard [40].

If studies in Brazil and the United Kingdom used the CLSI 2015 standard, the reduced susceptibility rate to penicillin would have been different $[3,4]$. With standards from the Brazilian study (CLSI 2006, S. aureus to penicillin), our data found resistant isolates to penicillin at least as many as a quarter of the total isolates. If the study by Perreira et al. used CLSI 2015 as standard, the resistance rate would be zero and the reduced susceptibility rate would only be $10 \%$, while if the study by
Engler et al. used CLSI 2015, none of the isolates would be categorized as resistant.

In Indonesia, a recent research in 2018 by Sariadji et al. from the Indonesian National Institute of Health Research and Development reported that $10.5 \%$ (6 of 57) of $C$. diphtheriae isolates were resistant to penicillin. The disk diffusion method $(10 \mu \mathrm{g}$ penicillin and $15 \mu \mathrm{g}$ erythromycin) and CLSI 2010 were used in this study. The MIC standard of penicillin in CLSI 2010 is different from CLSI 2015, the newer edition. Most of these isolates were collected from the western side of Indonesia [43]. If our study used the CLSI 2010 as standard, the susceptibility rate to penicillin would be better. Until now, the majority of institutions and guidelines still recommend penicillin as the drug of choice for the treatment of diphtheria. At the same time, some authors hypothesized that penicillin 
tolerance has been the cause of $C$. diphtheriae infection treatment failure $[3,10,21,23]$.

In this study, MIC range to oxacillin was higher than that to penicillin. The MIC range to oxacillin was 1 to $96 \mu \mathrm{g} / \mathrm{L}$. The susceptibility evaluation could not be done for this drug since there was no standard in CLSI 2015. In Brazil, a study by Perreira et al. reported that 46 of 47 isolates showed resistance to oxacillin and/or ampicillin [3]. Another case report by Pennie et al. about the misidentification of toxigenic $C$. diphtheriae in a child with endocarditis revealed resistance to oxacillin but susceptibility to other antimicrobial agents such as penicillin G and erythromycin [47]. In France, Patey et al. showed that all isolates (38 of 38) were susceptible to amoxicillin [39]. Some older studies by Weiss et al., MartinezMartinez et al., and Perreira et al. applied breakpoints of other bacteria, mostly $S$. aureus, to penicillin, oxacillin, and ampicillin to evaluate $C$. diphtheriae $[3,17,48,49]$. Based on the high MIC level in this study we predicted that oxacillin could not be used for diphtheria.

The WHO Manual for laboratory diagnosis of diphtheria describes that erythromycin is marginally more active than penicillin [9]. Several experts and guidelines consider erythromycin as a drug of choice because it has better in vitro activity than penicillin, such as in the Vietnam study (MIC range, $0.025-0.05 \mathrm{mg} / \mathrm{L}$ ) [5]. However, in other studies, erythromycin was reported to have high resistance $[3-5,43]$, while in our study, it was still susceptible in $85.2 \%$ of the isolates (92 of 108). Although $12 \%$ (13 of 108) of the isolates had decreased susceptibility but the resistance rates were relatively low, only $2.8 \%$ (3 of 108) had MIC of 2, 192, and $>256 \mu \mathrm{g} / \mathrm{L}$. Overall, the susceptibility to erythromycin in this study was better than that to penicillin.

The first report of erythromycin-resistant strain was in 1973 by Jellard and Lipinski [50]. Farfour et al. in 2011 evaluated 42 invasive $C$. diphtheriae isolates. All isolates were susceptible to erythromycin, but six of them had reduced susceptibility to penicillin G (MIC range, 0.38$0.5 \mathrm{mg} / \mathrm{L}$ ) [51]. If Farfour et al. used CLSI 2015 as standard, none of the isolates would be categorized as resistant to penicillin. Pereira et al. also reported that most $C$. diphtheriae isolates were sensitive to erythromycin $\left(\mathrm{MIC}_{90}, 0.75 \mu \mathrm{g} / \mathrm{mL}\right.$ ), and only $4.2 \%$ (2 of 47 ) of the isolates showed decreased susceptibility (MIC, $1.0 \mu \mathrm{g} / \mathrm{mL}$ ) [3]. Engler et al. in the United Kingdom found only 5 of 410 isolates with reduced susceptibility to erythromycin and other macrolides. These isolates came from Australia and Vietnam [4]. A study in Thailand found high susceptibility to erythromycin [19]. A similar reported was found in Algeria, in which 100\% (157 of 157) were susceptible to erythromycin [40]. This result was similar to a study in Delhi, India (54 of 54 isolates) [45]. Patey et al., in France found 2 of 38 isolates with reduced susceptibility to erythromycin [39]. In Indonesia, Rockhill et al. reported the susceptibility of all isolates to erythromycin (133 of 133); recently, Sariadji et al. reported that only 5.3\% (3 of 57) of the isolates were resistant to erythromycin [42, 43]. Other studies in other countries showed resistance of $C$. diphtheriae to erythromycin [5, 39, 52]. In Vietnam, 27\% (4 of 15) of isolates showed decreased susceptibility to erythromycin. The author also reported slower fever clearance and higher gastrointestinal side effects associated with this drug [5]. Bernard et al., in Canada showed reduced susceptibility of 33 of 195 (16.9\%) C. diphtheriae isolates to erythromycin [20].

Zasada recorded more publications of erythromycinresistant $C$. diphtheriae compared to penicillin-resistant isolates [17]. Resistance to erythromycin could occur in the sub-inhibition level of that antibiotic. Some investigators found the plasmid-mediated resistance pattern [5, 53]. Others described the gene acquisition related resistant mechanism, such as the ermX (erythromycin methylase enzyme class X) gene in Corynebacterium spp [5, 17]. Barraud et al. found that $C$. diphtheriae can harbor integrons. This genetic feature would give the isolates the capability to easily acquire new gene cassettes, such as erm, which encode resistance to erythromycin [54].

This study could not evaluate the susceptibility to azithromycin and clarithromycin due to the absence of the accepted breakpoints for Corynebacterium in CLSI 2015. We considered that the MIC data for azithromycin and clarithromycin did not show much difference from the MIC data for erythromycin (all macrolides had the same MIC range). Our data showed higher MIC for gravis biotype, as also found in penicillin. Engler et al. in the United Kingdom found that all isolates with reduced susceptibility to erythromycin also showed reduced susceptibility to azithromycin and clarithromycin. Based on the MIC, the authors stated that the clarithromycin was the most active among other macrolides $\left(\mathrm{MIC}_{90}\right.$ for clarithromycin, erythromycin, roxithromycin, and azithromycin was 0.008 , $0.026,0.03$, and $0.058 \mu \mathrm{g} / \mathrm{L}$, respectively) [4]. According to Wilson, the advantages of clarithromycin are as follows: it has fewer side effects and could be given twice daily. Azithromycin can be given once daily with also fewer gastrointestinal side effects than erythromycin. These three macrolides might have a similar activity against $C$. diphtheriae in vitro [55]. In Pereira et al. study, azithromycin $\left(\mathrm{MIC}_{90}, 0.064 \mu \mathrm{g} / \mathrm{mL}\right)$ was active against $C$. diphtheriae [3]. Patey et al in 1997 showed a similar activity between erythromycin and azithromycin [56].

Our results showed that all isolates with reduced susceptibility to erythromycin had high MIC to azithromycin and partly also to clarithromycin. These isolates also had reduced susceptibility to penicillin. Once again, all isolates with resistance or lower susceptibility were 
gravis. To our knowledge, in the literature, the studies about the resistance pattern to azithromycin and clarithromycin were limited, most probably because the MIC standard for both macrolides was not available.

As there were no resistant isolates to penicillin in this study, we could not evaluate the multiresistant $C$. diphtheriae. These multiresistant isolates were reported in some other studies, with various definitions. Perreira et al. in Brazil showed antimicrobial multiresistance patterns of $95.74 \%$ ( 45 of 47 ) C. diphtheriae strains to 4 to 7 antibiotics. Only 2 of 47 isolates did not show the multiresistance state [3]. In Vietnam, 3 of 15 (20\%) isolates were multiresistant to penicillin and erythromycin [5]. A previous study in Indonesia by Sariadji et al found $12 \%$ multiresistant isolates, which included 4 of 57 isolates that were resistant to 3 to 5 antibiotics [43]. In Canada, at least 18 multiresistant isolates were reported by Bernard et al [20]. The first case of multiresistant $C$. diphtheriae in Canada was resistant to erythromycin (MIC, $2 \mu \mathrm{g} / \mathrm{L}$ ) and some other antibiotics, but not penicillin. Broth microdilution was used in this study [18]. However, data from Russia (2.3\%), India (0\%), and Poland $(0 \%)$ showed very limited multiresistant strains $[45,57,58]$.

The main implication of this study would affect the antibiotic choice in Indonesia. At present, penicillin was more recommended than erythromycin. Our result showed that the erythromycin was better than penicillin.

Antibiotic resistance variability, in terms of time of incidence, and types of antibiotic, was found not only in Indonesia $[42,43]$, but also all over the world $[3-5,19$, $20,40,41,58]$. Good quality and exact recommendation would not be possible without regular susceptibility testing [19, 20, 40,43]. Although at this moment our country was not able to do this recommendation, it should be put as one of the priorities.

This study used the E-test based on practicability and easiness, but it is not the standard method according to the CLSI. However, many published literatures used E-test, [3, $4,40,59,60]$ and the disk diffusion method, [3, 5, 39, 43] and, for more recent studies, standard broth microdilution methods $[19,20,61]$. Several literatures found high correlation of the E-test and the disk diffusion method [3, 4, 17, $48,49,59]$.

The other limitation of this study was we did not examine the deoxyribonucleic acid (DNA) sequence of C. diphtheriae to analyze the association between the genetic aspect and the MIC. Genetic information is suggested to be done regularly [62]. Further study may be focused in this issue.

\section{Conclusions}

The susceptibility rate of toxigenic $C$. diphtheriae isolates to erythromycin is better than that to penicillin.
The updated version of antibiotic selection and choice in the national guidelines for diphtheria is recommended. This may include the willingness to provide erythromycin injection, which is not available in Indonesia at this moment. Moreover, many variations of antibiotic resistance from many parts of the world, and minimal data from our country lead to the need for regular susceptibility testing. The international MIC reference standard for other macrolide groups, especially azithromycin and clarithromycin is also needed.

\section{Abbreviations}

ADS: Antidiphtheria serum; BAP: Blood agar plate; BBLK: Balai besar laboratorium kesehatan; CDC: Center for disease control and prevention; CLSI: The clinical and laboratory standard institute; DNA: Deoxyribonucleic acid; I: Intermediate; MIC: Minimum inhibitory concentration; R: Resistant; S: Susceptible; UK: The United Kingdom; WHO: World Health Organization

\section{Acknowledgments}

We thank the management and staff of the BBLK Surabaya for a great collaboration. We want to thank Enago (www.enago.com) for the English language review.

\section{Authors' contributions}

$\mathrm{DH}$ made the grand design of the study, analyzed and interpreted the data, searched the literature, and wrote the draft and the final manuscript. SDP collected, analyzed, and interpreted the data, searched the literature, and drafted the manuscript. ISK collected and analyzed the data, including the laboratory works, and also reviewed the manuscript. AP analyzed and interpreted the data, added some of the literature, and reviewed the manuscript. El added some aspects in the initial design, analyzed and interpreted the data, added some of the literature, and reviewed the manuscript. DP codirected the data collection, supported the data analysis, and reviewed the manuscript. LK codirected the data collection, supported the data analysis, and reviewed the manuscript. PSB analyzed and interpreted the data, wrote some parts of the manuscript, and reviewed the final manuscript. IM finalized the initial design, analyzed and interpreted the data, and reviewed the final manuscript. All authors have read and approved the manuscript.

\section{Funding}

The Airlangga University and KSPITA Surabaya gave partial funding for this publication. Both funders did not interfere with the whole research process.

Availability of data and materials

The raw dataset of MIC is included as supplementary material.

Ethics approval and consent to participate

The study was approved by The Ethical Committee of Health Research, Faculty of Medicine, Universitas Airlangga. The certificate number was 241/ EC/KEPK/FKUA/2018 (20 August 2018). Consent to participate is not applicable (the study used the isolates in the Balai Besar Laboratorium Kesehatan Daerah, Surabaya). The consent was waived by the Ethical Committee.

\section{Consent for publication}

Not applicable.

\section{Competing interests}

The authors declare that they have no competing interests.

\section{Author details}

${ }^{1}$ Department of Child Health, Faculty of Medicine Universitas Airlangga/Dr. Soetomo Academic General Hospital, Surabaya, Indonesia. ${ }^{2}$ Balai Besar Laboratorium Kesehatan Daerah (BBLK), Surabaya, Indonesia. 
Received: 4 September 2019 Accepted: 29 November 2019 Published online: 11 December 2019

\section{References}

1. Hughes GJ, Mikhail AF, Husada D, Irawan E, Kafatos G, Bracebridge S, Pebody R, Efstratiou A. Seroprevalence and determinants of immunity to diphtheria for children living in two districts of contrasting incidence during an outbreak in East Java, Indonesia. Pediatr Infect Dis J. 2015;34(11):1152-6.

2. Husada D, Puspitasari D, Kartina L, Basuki PS, Moedjito I, Kartiko BW. Six-year surveillance of diphtheria outbreak in Indonesia. Open Forum Infect Dis. 2017:4(Suppl 1):S224.

3. Pereira GA, Pimenta FP, Dos Santos FRW, Damasco PV, Junior RH, MattosGuaraldi AL. Antimicrobial resistance among Brazilian Corynebacterium diphtheriae strains. Mem Inst Oswaldo Cruz. 2008;103:507-10. https://doi.org/10.1590/S0074-02762008000500019.

4. Engler KH, Warner M, George RC. In vitro activity of ketolides HMR 3004 and HMR 3647 and seven other antimicrobial agents against Corynebacterium diphtheriae. J Antimicrob Chemother. 2001;47:27-31.

5. Kneen R, Pham NG, Solomon T, Tran TM, Nguyen TT, Tran BL, Wain J, Day NP, Tran TH, Parry CM, White NJ. Penicillin vs. erythromycin in the treatment of diphtheria. Clin Infect Dis. 1998;27:845-50.

6. Zamiri I, McEntegart MG. The sensitivity of diphtheria bacilli to eight antibiotics. J Clin Pathol. 1972;25:716-7.

7. Both L, White J, Mandal S, Efstratiou A. Access to diphtheria antitoxin for therapy and diagnostics. Euro Surveill. 2014;19:20830. https://doi.org/10.2807/1560-7917.ES2014.19.24.20830.

8. Smith HL, Saia G, Lobikin M, Tiwari T, Cheng SC, Molrine DC. Characterization of serum anti-diphtheria antibody activity following administration of equine anti-toxin for suspected diphtheria. Hum Vaccin Immunother. 2017;13(11):2738-41.

9. Begg N. Diphtheria manual for the management and control of diphtheria in the European region. Copenhagen: WHO Regional Office for Europe; 1994.

10. Centers for Disease Control and Prevention (CDC). Corynebacterium diphtheriae. In: Hamborsky J, Kroger A, Wolfe S, editors. Epidemiology and prevention of vaccine-preventable diseases. Washington, DC: Public Health Foundation; 2015. p. 107-18.

11. Napier W. Penicillin in the treatment of diphtheria. Br Med J. 1947;2(4526):547-8

12. Adler NR, Mahony A, Friedman ND. Diphtheria: forgotten, but not gone. Intern Med J. 2013;43:206-10. https://doi.org/10.1111/imj.12049.

13. Abulmagd S, Emara M, Aziz S, El-Domany R. Evaluation and characterization of $A$ and $B$ fragments of Corynebacterium diphtheriae toxin towards recombinant diphtheria vaccine. Indian J Med Microbiol. 2013;31:3-9. https://doi.org/10.4103/0255-0857.108702.

14. Meera M, Rajarao M. Diphtheria in Andhra Pradesh-a clinicalepidemiological study. Int J Infect Dis. 2014;19:74-8. https://doi.org/10.1016/j.ijid.2013.10.017.

15. Both L, Collins S, De Zoysa A, White J, Mandal S, Efstratiou A. Molecular and epidemiological review of toxigenic diphtheria infections in England between 2007 and 2013. J Clin Microbiol. 2015;53:567-72 https://doi.org/10.1128/JCM.03398-14.

16. Mattos-Guaraldi AL, Moreira LO, Damasco PV, Junior RH. Diphtheria remains a threat to health in the developing world - an overview. Mem Inst Oswaldo Cruz (Rio). 2003;98(8):987-93.

17. Zasada AA. Antimicrobial susceptibility and treatment. In: Burkovski A, editor. Corynebacterium diphtheriae and related toxigenic species genomics, pathogenicity and applications. New York: Springer; 2014. p. 239-46.

18. Mina NV, Burdz T, Wiebe D, Rai JS, Rahim T, Shing F, Hoang L, Bernard K Canada's first case of multidrug-resistant Corynebacterium diphtheriae strain, isolated from a skin abscess. J Clin Microbiol. 2011:49(11):4003-5.

19. Paveenkittiporn W, Sripakdee S, Koobkratok O, Sangkitporn S, Kerdsin A. Molecular epidemiology and antimicrobial susceptibility of outbreak associated Corynebacterium diphtheriae in Thailand, 2012. Infect Genet Evol. 2019;75:104007.

20. Bernard K, Pacheco AL. In vitro activity of 22 antimicrobial agents against Corynebacterium and Micobacterium species referred to the Canadian National Microbiology Laboratory. Clin Microbiol Newsl. 2015;37(23):187-98.

21. Santos LS, Sant'Anna LO, Ramos JN, Ladeira EM, Stavracakis-Peixoto R, Borges LL, Santos CS, Napoleao F, Camello TC, Pereira GA, Hirata R, Vieira W, Cosme LM, Sabbadini PS, Mattos-Guiaraldi AL. Diphtheria outbreak in Maranhão, Brazil: microbiological, clinical and epidemiological aspects. Epidemiol Infect 2015:143:791-8. https://doi.org/10.1017/S0950268814001241.
22. McComb JM, Campbell NP, Cleland J. Recurrent ventricular tachycardia associated with QT prolongation after mitral valve replacement and its association with intravenous administration of erythromycin. Am J Cardiol. 1984:54(7):922-3.

23. World Health Organization. Operational protocol for clinical management of Diphtheria Bangladesh, Cox's Bazar. 2017. https://www.who.int/healthcluster/resources/publications/WHO-operational-protocols-diphtheria. pdf?ua=1. Accessed 20 Aug 2019.

24. Veeraraghavan B, Pragasam AK, Bakthavatchalam YD, Ralph R. Typhoid fever: issues in laboratory detection, treatment options, \& concerns in management in developing countries. Future Sci Open Access. 2018;04(06):FS0312.

25. National Institute for Communicable Disease. Diphtheria: NICD recommendations for diagnosis, management. 2016. http://www.nicd.ac.za/ wp-content/uploads/2017/03/NICD-quidelines diphtheria_v3_28-May-2018. pdf. Accessed 20 Aug 2019.

26. Amsden GW. Erythromycin, clarithromycin, and azithromycin: are the differences real? Clin Ther. 1996;18(1):56-72.

27. Chambers HF. Penicillins and b-lactam inhibitors. In: Hamborsky J, Kroger A, Wolfe S, editors. Mandell, Douglas, and Bennett's principles and practice of infectious diseases. 27th ed. Philadelphia: Elsevier; 2010. p. 317-27.

28. Efstratiou A, Maple C. Laboratory diagnosis of diphtheria. Copenhagen: World Health Organization; 1994

29. Engler KH, Glushkevich T, Mazurova IK, George RC, Efstratiou A. A modified Elek test for detection of toxigenic corynebacteria in the diagnostic laboratory. J Clin Microbiol. 1997;35(2):495-8.

30. Estivariz CF, Watkins MA, Handoko D, Rusipah R, Deshpande J, Rana BJ, Irawan E, Widhiastuti D, Pallansch MA, Thapa A, Imari S. A large vaccinederived poliovirus outbreak on Madura Island, Indonesia, 2005. J Infect Dis. 2008;197(3):347-54

31. Clinical and Laboratory Standard Institute. Methods for antimicrobial dilution and disk susceptibility testing of infrequently isolated or fastidious bacteria, CLSI Guideline M45. 3rd ed. Wayne: Clinical and Laboratory Standards Institute; 2015

32. Lai Y, Purnima P, Ho M, Ang M, Deepak RM, Chew KL, Vasoo S, Capulong $D F$, Lee $V$. Fatal case of diphtheria and risk for reemergence, Singapore. Emerg Infect Dis. 2018;24(11):2084-6.

33. Lodeiro-Colatosti A, Reischi U, Holzmann T, Hernandez-Pereira CE, Risquez A, Paniz-Mondolfi AE. Diphtheria outbreak in Amerindian communities, Wonken, Venezuela, 2016-2017. Emerg Infect Dis. 2018;24(7):1340-4.

34. Wagner KS, White JM, Crowcroft NS, De Martin S, Mann G, Efstratiou A. Diphtheria in the United Kingdom, 1986-2008: the increasing role of Corynebacterium ulcerans. Epidemiol Infect. 2010;138:1519-30. https://doi.org/10.1017/S0950268810001895

35. Ministry of Health of Indonesia (Kementerian Kesehatan Republik Indonesia). Pedoman surveilans dan penanggulangan difteri (Guideline for surveillance and outbreak of diphtheria). Jakarta: Kemenkes Republik Indonesia; 2018.

36. Vitek CR, Wharton M. Diphtheria in the former Soviet Union: reemergence of a pandemic disease. Emerg Infect Dis. 1998;4:539-50.

37. World Health Organization. Diphtheria vaccine: WHO position paper, August 2017. Wkly Epidemiol Res. 2017;92:417-35.

38. Murhekar M. Epidemiology of diphtheria in India, 1996-2016: implications for prevention and control. Am J Trop Med Hyg. 2017;97(2):313-8.

39. Patey O, Bimet F, Emond JP, Estrangin E, Riegel PH, Halioua B, Dellion S, Kiredjian M. Antibiotic susceptibility of 38 non-toxigenic strains of Corynebacterium diphtheriae. J Antimicrob Chemother. 1995;36:1108-10.

40. Benamrouche N, Hasanoui S, Badell E, Guettou B, Lazri M, Guiso N, Rahal K. Microbiological and molecular characterization of Corynebacterium diphtheriae isolated in Algeria betweeen 1992 and 2015. Clin Microbiol Infect. 2016:22:1005.e1-7.

41. Khalid MKNM, Ahmad N, Hii SYF, Wahab MAA, Hashim R, Liow YL. Molecular characterization of Corynebacterium diphtheriae isolates in Malaysia between 1981 and 2016. J Med Microbiol. 2019;68(1):105-10. https://doi.org/10.1099/jmm.0.000881.

42. Rockhill RC, Sumarmo HH, Siregar SP, Muslihun B. Tetracycline resistance of Corynebacterium diphtheriae isolated from diphtheria patients in Jakarta, Indonesia. Antimicrob Agents Chemother. 1982;21:842-3.

43. Sariadji K, Sunarno S, Puspandari N, Sembiring M. Antibiotic susceptibility pattern of Corynebacterium diphtheriae isolated from outbreaks in Indonesia 2010-2015. Indones Biomed J. 2018;10:51. https://doi.org/10.18585/inabj.v10i1.331. 
44. Czajka U, Wiatrzyk A, Mosiej E, Forminska K, Zasada AA. Changes in MST profiles and biotypes of Corynebacterium diphtheriae isolates from diphtheria outbreak period to the period of invasive infections caused by nontoxigenic strains in Poland (1950-2016). BMC Infect Dis. 2018:18:121.

45. Sharma NC, Banavaliker JN, Ranjan R, Kumar R. Bacteriological and epidemiological characteristics of diphtheria cases in \& around Delhi - a retrospective study. Indian J Med Res. 2007;126:545-52.

46. Mohankumar S, Paschapur S, Mailare S. Epidemiology of diphtheria and antimicrobial resistance among diphtheria cases in Bijapur District, Karnataka, India, 2012-2015. Open Forum Infect Dis. 2018;5:243-4.

47. Pennie RA, Malik AS, Wilcox L. Misidentification of toxigenic Corynebacterium diphtheriae as a Corynebacterium species with low virulence in a child with endocarditis. J Clin Microbiol. 1996;34:1275-6.

48. Martinez-Martinez L, Ortega MC, Suarez Al. Comparison of E-test with broth microdilution and disk diffusion for susceptibility testing of coryneform bacteria. J Clin Microbiol. 1995;33:1318-21.

49. Weiss K, Laverdiere M, Rivest R. Antimicrobial susceptibilities of Corynebacterium species by broth microdilution and disk diffusion methods. Antimicrob Agent Chemother. 1996;40:930-3.

50. Jellard CH, Lipinski AE. Conynebacterium diphtheriae resistant to erythromycin and lincomycin. Lancet. 1973;1 (7795):156.

51. Farfour E, Badell E, Zasada A, HotzeGuillot S, Guiso N. Characterization and comparison of invasive Corynebacterium diphtheriae isolates from France and Poland. J Clin Microbiol. 2012;50:173-5. https://doi.org/10.1128/JCM.05811-11.

52. Gladin DP, Kozlova NS, Zaitzeva TK, Cherednichenko AS, Khaval AS. Sensitivity of Corynebacterium diphtheriae isolated in Saint Petersburg to antibacterial drugs. Antibiot Khimioter. 1999;44:17-21.

53. Serworld-Davis T, Groman N. Mapping and cloning of Corynebacterium diphtheriae plasmid pGN2 and characterization of its relatedness to plasmids from skin coryneforms. Antimicrob Agent Chemother. 1986;30:69-72.

54. Barraud O, Badell E, Denis F, Guiso N, Ploy MC. Antimicrobial drug resistance in Corynebacterium diphtheriae mitis. Emerg Infect Dis. 2011;17:2078-80. https://doi.org/10.1086/519383.

55. Wilson APR. Treatment of infection caused by toxigenic and non-toxigenic strains of Corynebacterium diphtheriae. J Antimicrob Chemother. 1995;35: 717-20.

56. Patey O, Bimet F, Riegel PH, Halioua B, Emond JP, Estrangin E, Dellion S, Alonso JM, Kiredjian M, Dublanchet A, Lafaix C. Clinical and molecular study of Corynebacterium diphtheriae systemic infections in France. J Clin Microbiol. 1997;35:441-5.

57. Maple PA, Efstratiou A, Tseneva G, Rikunshin Y, Deshevoi S, Jackola M, Vuopio-Varkila J, George RC. The in vitro susceptibilities of toxigenic strains of Corynebacterium diphtheriae isolated in northwestern Russia and surrounding areas to ten antibiotics. J Antimicrob Chemother. 1994:34:1037-40.

58. Zasada A, Baczewska-Rej M, Wardak S. An increase in non-toxigenic Corynebacterium diphtheriae infections in Poland - molecular epidemiology and antimicrobial susceptibility of strains isolated from past outbreaks and those currently circulating in Poland. Int J Infect Dis. 2010;14(10):e907-12.

59. Von Hunelstein C, Scopetti F, Efstratiou A, Engler K. Penicillin tolerance amongst non toxigenic Corynebacterium diphtheriae isolated from cases of pharyngitis. J Antimicrob Chemother. 2002;50:125-8.

60. Fernandez-Roblas R, Adames H, Martin de Hijas NZ, Almeida DG, Gadea I, Esteban $\mathrm{J}$. In vitro activity of tigecycline and 10 ther antimicrobials against clinical isolates of the genus Corynebacterium. Int J Antimicrob Agents. 2009;33:453-5.

61. Neemuchwala A, Soares D, Ravirajan V, Marchand-Austin A, Kus JV, Patel SN. In vitro antibiotic susceptibility pattern of non-diphtheriae Corynebacterium in Ontario, 2011-2016. Antimicrob Agents Chemother. 2018;62:e01776-17. https://doi.org/10.1128/AAC.01776-17.

62. Seth-Smith HMB, Egli A. Whole genome sequencing for surveillance of diphtheria in low incidence settings. Front Public Health. 2019;7:235. https://doi.org/10.3389/fpubh.2019.00235.

\section{Publisher's Note}

Springer Nature remains neutral with regard to jurisdictional claims in published maps and institutional affiliations.

\section{Ready to submit your research? Choose BMC and benefit from}

- fast, convenient online submission

- thorough peer review by experienced researchers in your field

- rapid publication on acceptance

- support for research data, including large and complex data types

- gold Open Access which fosters wider collaboration and increased citations

- maximum visibility for your research: over $100 \mathrm{M}$ website views per year

At BMC, research is always in progress.

Learn more biomedcentral.com/submissions 